\title{
COPD Due to Sulfur Mustard (Mustard Lung)
}

\author{
Shahrzad M. Lari, Davood Attaran and Mohammad Towhidi \\ Lung Disease and Tuberculosis Research Center, School of Medicine, \\ Mashhad University of Medical Sciences, Mashhad \\ Iran
}

\section{Introduction}

Sulfur Mustard (SM) is a potent toxic alkylating agent that has been used as a chemical warfare gas during the World War I and in the Iran-Iraq conflict between 1983 and 1988(1). SM can cause serious organ damages especially ocular, neurologic, cutaneous, bone marrow, and pulmonary complications (1). The previous studies have shown that the respiratory complications are the most common late complications of SM toxic exposure including chronic obstructive pulmonary disease (COPD), chronic bronchitis, bronchiolitis oblitrans, bronchiectasis, airway hyperresponsiveness, and lung fibrosis (2-6). The COPD which occur after SM exposure is known as "Mustard lung" (7). Since about 45000 patients are now suffering from long term complications of SM toxic exposure, the evaluation of its pathogenesis and finding the possible ways for treatment is necessary. During the last decade, especial attention to the possible underlying mechanism of COPD due to SM intoxications has been applied. Our previous studies have shown that in COPD patients due to SM exposure inflammatory markers (highly sensitive CRP, interleukin 6) are elevated and these markers have direct association with the severity of disease $(8,9)$. The finding which recommends the role of systemic inflammation in the pathogenesis of COPD due to SM intoxication like the COPD due to other causes. In this chapter the historical points, probable pathogenesis, clinical manifestation, and diagnosis of mustard lung will be discussed.

\section{Historical background}

Mustard gas was possibly developed as early as 1822 by César-Mansuete Desperetez (17981863) (10). SM was used as the late 1880 for treating minor tumors (11). Mustard gas is the most widely - used vesicant chemical war agent in the past century (2).Unfortunately SM was first employed effectively as a weapon in World War by the Germans on the British at Ypres $(3,11)$. It was then used during the Iran-Iraq war (1983-1988) and more than 100000 military and civilian people were injured by SM gas (12).Now, over 45000 patients are suffering from the late complications of SM exposure $(11,12)$ and now SM is included as a threat to both military and civilians (13).

\section{Sulfur mustard}

SM or [bis-(2-chloroethyl) sulfate] (Fig.1) is also known as" Yperite" (Ypres was the name of the place which it was first used), "Lost" (the initials of two German chemists), and "yellow 
cross" (it was a symbol means "skin damaging agent" during world war I) $(11,12)$.It is a colorless to yellowish- brown oily liquid at room temperature that converts to a gas with weapon system delivery $(3,11)$.It has the odor of mustard, garlic, or onion (3).

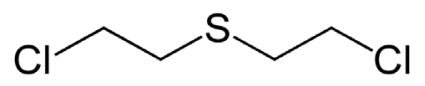

Fig. 1. Molecular structure of sulfur mustard

$\mathrm{SM}$ is absorbed by different ways: inhalation, through the skin, eyes, and gasterointestinal tract due to consumption of contaminated food (3 ).In large amount exposure, it can cause damages in rapid proliferating tissues particularly bone marrow (3).SM can cause different biochemical reactions and alterations in DNA structure (1).

\section{Classification}

Following the SM exposure, acute and late (long term) complications may occur. The long term complications of SM exposure are much serious than acute effects.Generally the long term effects of SM exposure occur several years after a mild contact and are totally different from continuous longtime exposure (mainly occupational exposure) $(12,13)$.Several studies in Iran demonstrated that the most common late complication are respiratory problems, including chronic obstructive pulmonary disease (COPD), chronic bronchitis, bronchiolitis obliterans, bronchiectasis, airway hyperreactivity, and lung fibrosis (3-6).Ophthalmologic and cutenous problems are also seen in this period. Unfortunately, the respiratory problems usually exacerbate over time (12).A unique form of COPD known as" Mustard lung" is frequently seen as a long term complication (7).

\section{Pathogenesis}

The exact mechanism of late pulmonary complication of SM exposure are not fully defined (14).Although the pathogenesis of COPD has completely determined and is mainly dependent on chronic inflammation and oxidative stress following activation of airway inflammatory cells, but there are few studies about the inflammatory basis of mustard lung $(8,9,15)$. The pathological studies have shown that mustard lung is a neutrophilic / lymphocytic disorder $(16,17)$.Also bronchiolar disease with varying degrees of inflammation as the main pathological finding, was demonstrated in a recent pathologic study in patients with sulfur mustard injury (18). According to the previous pathological studies, it seems that activation of inflammatory cells and generation of reactive oxygen species resulting in oxidative stress be involved $(16,17)$. It has been shown that decreased glutathione and increased serum malondialdehyde levels in mustard lung patients can be an indicator of oxidative-antioxidative system imbalance (16). The previous animal model studies have mentioned that the activation of inflammatory cells are involved in the pathogenesis of SM lung injury $(19,20)$.It is well documented that oxidative antioxidative imbalance may result in oxidative stress and triggering inflammatory process (21).

Despite the accepted role of inflammatory cytokines in acute pulmonary complications of SM, there are limited studies on the level of cytokines in the long term complications of SM 
injury .Our recent studies $(8,9)$ on 50 stable mustard lung patients with all stages according to GOLD (Global Initiative for Chronic Obstructive Lung Disease) classification (Fig.2) (22),showed that despite the exclusion of smoking, cardiovascular diseases, infections, and other important inflammatory conditions, serum level of highly sensitive $\mathrm{c}$ reactive protein (hs-CRP) and interleukin 6 (IL-6), as inflammatory markers, are elevated in mustard lung patients in comparison of normal controls and are directly related to severity of COPD according to spirometry findings (Fig.3,4)(8,9). It is clearly documented that IL-6 has an important part in reduced forced expiratory volume in one second (FEV1), impaired functional capacity, and worsening the underlying inflammatory condition by release of acute phase proteins $(23,24)$. Also the previous studies in COPD patients have shown that the serum hs-CRP is related to severity of airflow obstruction $(25,26)$.

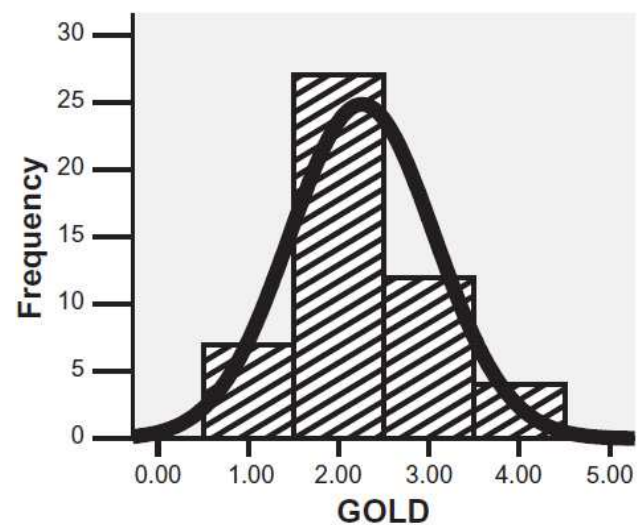

Fig. 2. The frequency of GOLD stages in mustard lung patients (9)

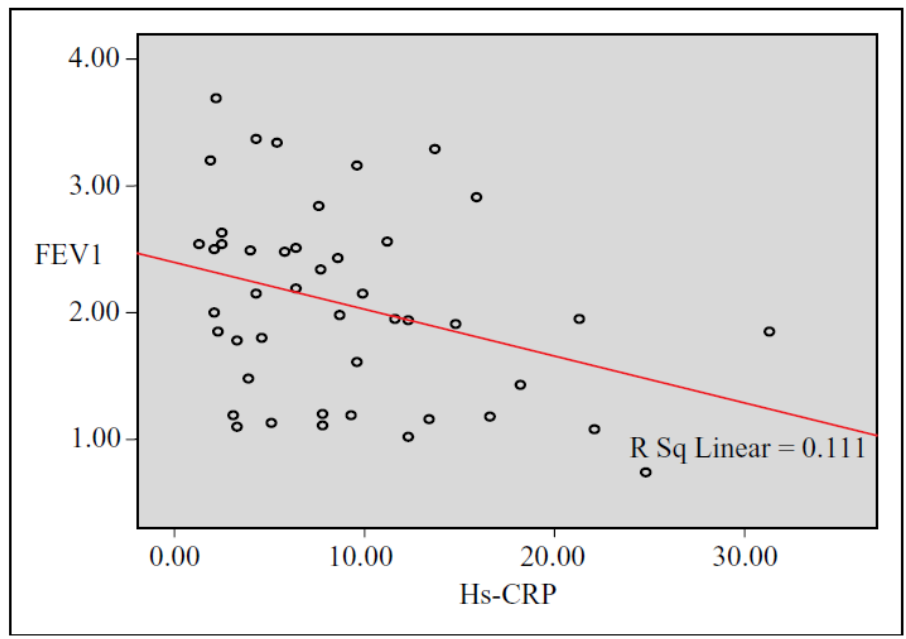

Fig. 3. The correlation of FEV1 and hs-CRP in mustard lung patients (8) 


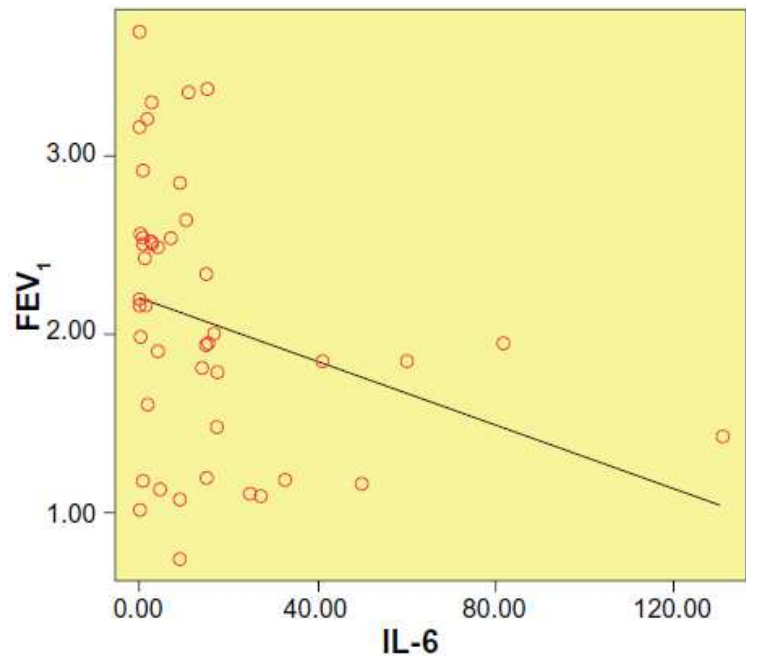

Fig. 4. The correlation of FEV1 and IL-6 in mustard lung patients (9)

Furthermore, the BODE (body mass index, obstruction, dyspnea, and exercise capacity) index, that is more reliable parameter of COPD morbidity and mortality, was significantly correlated with the serum IL-6 level (Fig 5) (9).

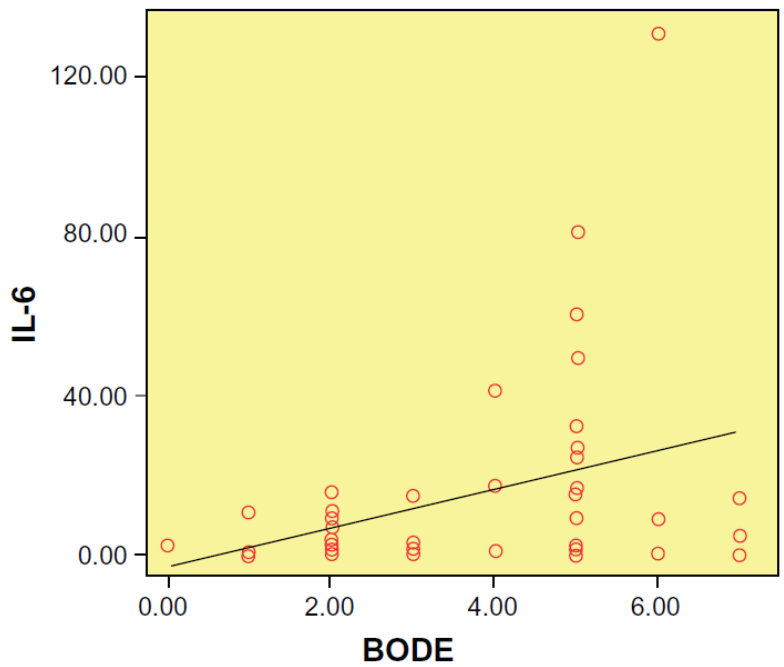

Fig. 5. The correlation of BODE index and serum IL-6 (9)

Additionally increased levels of IL-8 in the bronchoalveolar lavage fluid of patients with sulfur mustard poisoning and late pulmonary complications have been demonstrated (15) Despite these studies, few studies reported that inflammatory mediators probably do not have any major role in the pathogenesis and persistence of pulmonary complications of sulfur mustard exposure (27). 
These findings provide evidence of the possibility of an inflammatory basis for the late pulmonary complications of sulfur mustard exposure and is in accordance with previous studies in other COPD patients which pointed out that, even during the stable phase of COPD, serum levels of inflammatory markers, including IL-6, may be raised $(8,9)$

\section{Clinical manifestations}

The most common compliant of mustard lung patients is chronic cough (12).A study showed that a triad of cough, expectoration and dyspnea was found in more than $80 \%$ of Iranian veterans 3 years after the exposure $(1,28)$.

On physical examination, crackles, wheezing, and rhonchi depending to the state of the patient, can be seen $(12,29)$.The attacks of COPD exacerbation with increasing the severity of dyspnea, cough, and discoloration of sputum, is a common clinical presentation $(12,30)$.

The late pulmonary complications of SM injury may occur in patients who had not developed acute symptoms (12).A study on patients who did not have acute symptoms showed that $38 \%$ of these patients had air trapping on high resolution CT (HRCT) of chest (31).

Our previous studies on exercise tolerance of mustard lung patients have shown that the mean exercise capacity of these patients measured by 6 minute walk distance test (6MWD) has been decreased in comparison of normal population $(8,9)$.Also the evaluation of quality of life in mustard lung patients showed significant impairment in this assessment by saint George respiratory questionnaire (SGRQ) $(8,9,32)$.Additionally ,in our study the BODE (body mass index, obstruction, dyspnea, and exercise capacity) index had significant correlation with the serum level of inflammatory markers $(8,9)$.

\section{Diagnostic evaluation}

\section{Pulmonary function tests}

Spirometry is a common diagnostic way for staging the severity of pulmonary impairment. Like to COPD due to other causes, generally an obstructive pattern is present in patients. A study showed that FEV1 is decreased at a rate of $50 \mathrm{ml} /$ year in mustard lung patients $(11,33)$.

In body plethysmography, total lung capacity (TLC) and residual volume (RV) are markedly increased and Diffusing Capacity of the Lung for Carbon Monoxide (DLCO) remains normal $(11,34)$.

\section{Chest x-ray}

Since the majority of mustard lung patients have normal or near normal chest x-ray (CXR), some authors believe that CXR is not a reliable diagnostic imaging modality in these patients $(12,35)$. Increased bronchovascular markings, and hyperinflation, pulmonary hypertension can be seen in CXR $(12,36)$.

\section{HRCT}

Chest HRCT has became a imaging modality of choice in SM patients (12).Air trapping and airway abnormal wall thickening are the most common HRCT finding $(12,37)$. 


\section{Treatment}

Unfortunately, there are no cure for mustard lung disease (11 ).Bronchodilators, inhaled steroids, long- term oxygen therapy, and pulmonary rehabilitation are different therapeutical strategies which are used in these patients (11).The combination of long acting beta agonists (LABAs) and inhaled steroids has been shown to be effective $(11,38,39)$.

In mustard lung patients, systemic steroid is only recommended during exacerbations (11).The prolonged use of systemic steroids should be avoided because of severe complication (39).

As we mentioned earlier, the oxidative - antioxidative imbalance may be an underlying mechanism in mustard lung patients. So the potent antioxidant agents are tried for this purpose. N-Acetylcysteine is an antioixidat and mucolytic drug that in double- blind clinical trial, improved dyspnea, cough, and sputum after 4 months of treatment $(11,40)$.

\section{Conclusion}

SM can cause serious late pulmonary complications. A unique form of COPD, known as mustard lung, is frequently encountered in patients .Systemic inflammation may be involved in pathogenesis of mustard lung. Unfortunately there is no cure for these patients.

\section{References}

[1] Balali-Mood M, Hefazi M. Comparison of early and late toxic effects of sulfur mustard in Iranian veterans.Basic Clin Pharmacol Toxicol 2006; 99: 273-282.

[2] Ghanei M, Amiri S, Akbari H, et al. Correlation of sulfur mustard exposure and tobacco use with expression (immunoreactivity) of p53 protein in bronchial epithelium of Iranian "mustard lung" patients. Mil Med. 2007;172:70-74.

[3] Balali-Mood M, Hefazi M, Mahmoudi M, et al. Long-term complications of sulfur mustard poisoning in severely intoxicated Iranian veterans. Fundam Clin Pharmacol. 2005;19:713-721.

[4] Khateri S, Ghanei M, Keshavarz S, Soroush M, Hainez D. Incidence of lung, eye, and skin lesions as late complications in 34,000 Iranians with wartime exposure to mustard agent. J Occup Environ Med. 2003;45:1136-1143.

[5] Jafari M, Ghanei M. Evaluation of plasma, erythrocytes, and bronchoalveolar lavage fluid antioxidant defense system in sulfur mustard-injured patients. Clin Toxicol (Phila). 2010;48:184-192.

[6] Wigenstam E, Rocksén D, Ekstrand-Hammarstrom B, Bucht A. Treatment with dexamethasone or liposome-encapsuled vitamin E provides beneficial effects after chemical-induced lung injury. Inhal Toxicol. 2009;21:958-964.

[7] Ghanei M, Amiri S, Akbari H, et al. Correlation of sulfur mustard exposure and tobacco use with expression (immunoreactivity) of p53 protein in bronchial epithelium of Iranian "mustard lung" patients. Mil Med 2007; 172: 70-74.

[8] Attaran D, Lari SM, Khajehdaluee M, et al. Highly sensitive C-reactive protein levels in Iranian patients with pulmonary complication of sulfur mustard poisoning and its correlation with severity of airway diseases.Hum Exp Toxicol. 2009; 28:739 -745. 
[9] Attaran D, Lari SM, Towhidi M, et al. Interleukin-6 and airflow limitation in chemical warfare patients with chronic obstructive pulmonary disease. Int J Chron Obstruct Pulmon Dis. $2010 ; 5: 335-40$.

[10] By Any Other Name: Origins of Mustard Gas. Itech.dickinson.edu (2008-04-25). Retrieved on 2011-05-29.

[11] Ghanei M, Harandi AA.The respiratory toxicities of mustard gas. IJMS 2010;35:273-280.

[12] Ghanei M, Adibi I. Clinical review of mustard lung. IJMS 2007; 32: 58-65.

[13] Ray R, Simbulan-Rosenthal CM, Keyser BM, et al.Sulfur mustard induces apoptosis in lung epithelial cells via a caspase amplification loop. Toxicology 2010:271; 94-99.

[14] Ebrahimi M, Habibi MH, Imani AF, et al.Discrepency between mRNA and protein expression neutrophil gelatinase- associated lipocalin in bronchial epithelium by sulfur mustard. J Biomed Biotechnol;2010:823131.

[15] Emad A, Emad Y. Levels of cytokine in bronchoalveolar lavage (BAL)fluid in patients with pulmonary fibrosis due to sulfur mustard gasinhalation. I Interferon Cytokine Res. 2007;27:38-43.

[16] Shohrati M, Ghanei M, Shamspour N, et al. Erratum to: Glutathioneand malondialdehyde levels in late pulmonary complications of sulfur mustard intoxication. Lung. 2010;188:77-83.

[17] Ghanei M, Shohrati M, Jafari M, Ghaderi S, Alaeddini F, Aslani J.N-acetylcysteine improves the clinical conditions of mustard gasexposed patients with normal pulmonary function test. Basic Clin Pharmacol Toxicol. 2008;103:428-432.

[18] Ghanei M, Tazelaar HD, Chilosi M, et al. An international collaborative pathologic study of surgical lung biopsies from mustard gas-exposed patients. Respir Med. 2008;102:825-830.

[19] Kumar O, Sugendran K, Vijayaraghavan R. Protective effect of various antioxidants on the toxicity of sulfur mustard administered to mice by inhalation or percutaneous routes. Chem Biol Interact. 2001;134:1-12.

[20] Vijayaraghavan R, Gautam A, Kumar O, et al. Protective effect of ethanolic and water extracts of sea buckthorn (Hippophae rhamnoidesL.) against the toxic effects of mustard gas. Indian J Exp Biol. 2006;44:821-831.

[21] MacNee W. Oxidants/antioxidants and COPD. Chest. 2000;117:S303-S317.

[22] Pauwels RA, Buist AS, Caleverley PM, Jenkins CR, Hurd SS. Global strategy for the diagnosis, management, and prevention of chronic obstructive pulmonary disease. NHLBI/WHO Global initiative for Obstructive Lung Disease (GOLD) workshop summary. Am J Respir Crit Care Med. 2001;163:1256-1276.

[23] Sin DD, Paul Man SF. Interleukin-6. Chest. 2008;133:4-6.

[24] He JQ, Foreman MG, Shumansky K, et al. Associations of IL6 polymorphisms with lung function decline and COPD. Thorax. 2009;64:698-704.

[25] deTorres JP, Cordoba-Lanus E, Lopez-Aguilar C, et al.C-reactive protein levels important predictive outcomes in stable COPD patients. Eur Respir J 2006; 27: 902-907.

[26] Pinto-Plata VM, Mullerova H, Toso JF, Feudjo-Tepie M, Soriano JB, Vessey RS. Creactive protein in patients with COPD, control smokers, and nonsmokers.Thorax 2006; 61: 23-28.

[27] Pourfarzam S, Ghazanfari T, Yaraee R, et al. Serum levels of IL-8 and IL-6 in the long term pulmonary complications induced by sulfur mustard: Sardasht-Iran Cohort Study. Int Immunopharmacol. 2009;9:1482-1488. 
[28] Ghanei M, Fathi H, Mohammad MM, et al.Long-term respiratory disorders of claimers with subclinical exposure to chemical warfare agents. Inhal Toxicol 2004; 16: 491-5.

[29] Ghanei M, Hosseini AR, Arabbaferani Z,ShahKarami E. Evaluation of Chronic Cough in Chemical Chronic Bronchitis Patients.Environmental Toxicology \& Pharmacology 2005; 20: 6-10.

[30] Hefazi M, Attaran D, Mahmoudi M, Balali-Mood M. Late respiratory complications of mustard gas poisoning in Iranian veterans.Inhal Toxicol 2005; 17: 587-92.

[31] Ghanei M, Fathi H, Mohammad MM, et al.Long-term respiratory disorders of claimers with subclinical exposure to chemical warfare agents. Inhal Toxicol 2004; 16: 491-5.

[32] Attaran D, Khajedaloui M, Jafarzadeh R, Mazloomi M. Health related quality of life in patients with chemical warfare induced COPD.Archives of Iranian Medicine. 2006;9:359-363.

[33] Heidarnejad H, Zendehdel N, Dastgiri S.Temporal trend of clinical and spirometric parameters in mustard gas victims: A ten year study. Arch Iran Med 1988; 1: 13-6.

[34] Beheshti J, Mark EJ, Hosein Akbaei HM,et al. Mustard Lung Secrets: Long Term Clinicopathological Study Following Mustard Gas Exposure. Pathol Res Pract 2006; 202: 739-44.

[35] Bagheri M H, Hosseini S K, Mostafavi SH,Alavi SA. High-resolution CT in chronic pulmonary changes after mustard gas exposure.Acta Radiol 2003; 44: 241-5.

[36] Ghanei M, Mokhtari M, Mohammad MM,Aslani J. Bronchiolitis obliterans following exposure to sulfur mustard: chest high resolution computed tomography. Eur JRadiol 2004; 52: 164-9.

[37] Emad AF, Rezaian GR, Hosseini K, Ghayyoomi SMA. Chronic pulmonary sequelaeof sulfur mustard gas exposure in man: A report of 36 Cases. Irn J Med Sci 1995; 20:1-4.

[38] 65 Sohrabpour H, Roshan-Zamir F, Aminorroya AP. Comparison of acute bronchodilatory effects of inhaled Sulbotamol and Combivent in mustard gas victims. Iran J Med Sci 1996; 21: 34.

[39] Ghanei M, Shohrati M, Harandi AA, et al.Inhaled corticosteroids and long-acting beta 2agonists in treatment of patients with chronic bronchiolitis following exposure to sulfur mustard. Inhal Toxicol 2007; 19:889-94.

[40] Shohrati M, Aslani J, Eshraghi m, et al.Therapeutics effect of $\mathrm{N}$-acetyl cysteine on mustard gas exposed patients: Evaluating clinical aspect in patients with impaired pulmonary function test. Respir Med 2008;102: 443-8. 


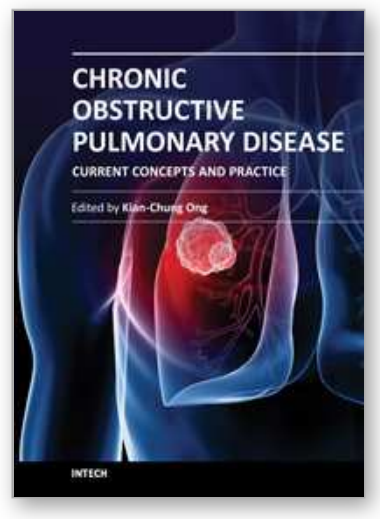

\author{
Chronic Obstructive Pulmonary Disease - Current Concepts and \\ Practice \\ Edited by Dr. Kian-Chung Ong
}

ISBN 978-953-51-0163-5

Hard cover, 474 pages

Publisher InTech

Published online 02, March, 2012

Published in print edition March, 2012

A decade or so ago, many clinicians were described as having an unnecessarily 'nihilistic' view of COPD. This has certainly changed over the years... This open access book on COPD provides a platform for scientists and clinicians from around the world to present their knowledge of the disease and up-to-date scientific findings, and avails the reader to a multitude of topics: from recent discoveries in the basic sciences to state-of-the-art interventions on COPD. Management of patients with COPD challenges the whole gamut of Respiratory Medicine - necessarily pushing frontiers in pulmonary function (and exercise) testing, radiologic imaging, pharmaceuticals, chest physiotherapy, intensive care with respiratory therapy, bronchology and thoracic surgery. In addition, multi-disciplinary inputs from other specialty fields such as cardiology, neuro-psychiatry, geriatric medicine and palliative care are often necessary for the comprehensive management of COPD. The recent progress and a multi-disciplinary approach in dealing with COPD certainly bode well for the future. Nonetheless, the final goal and ultimate outcome is in improving the health status and survival of patients with COPD.

\title{
How to reference
}

In order to correctly reference this scholarly work, feel free to copy and paste the following:

Shahrzad M. Lari, Davood Attaran and Mohammad Towhidi (2012). COPD Due to Sulfur Mustard (Mustard Lung), Chronic Obstructive Pulmonary Disease - Current Concepts and Practice, Dr. Kian-Chung Ong (Ed.), ISBN: 978-953-51-0163-5, InTech, Available from: http://www.intechopen.com/books/chronic-obstructivepulmonary-disease-current-concepts-and-practice/copd-due-to-sulfur-mustard-mustard-lung-

\section{INTECH}

open science | open minds

\section{InTech Europe}

University Campus STeP Ri

Slavka Krautzeka 83/A

51000 Rijeka, Croatia

Phone: +385 (51) 770447

Fax: +385 (51) 686166

www.intechopen.com

\section{InTech China}

Unit 405, Office Block, Hotel Equatorial Shanghai

No.65, Yan An Road (West), Shanghai, 200040, China 中国上海市延安西路65号上海国际贵都大饭店办公楼405单元

Phone: +86-21-62489820

Fax: +86-21-62489821 
(C) 2012 The Author(s). Licensee IntechOpen. This is an open access article distributed under the terms of the Creative Commons Attribution 3.0 License, which permits unrestricted use, distribution, and reproduction in any medium, provided the original work is properly cited. 